\title{
Ubiquitination-dependent, proteasomal degradation of the retroviral oncoprotein Tax by niclosamide, an anti-helminthic molecule
}

\author{
Di Xiang ${ }^{2}$, Yunsheng Yuan², Li Chen ${ }^{1}$, Chandra Belani ${ }^{2}$, Hua Cheng ${ }^{1 *}$ \\ From 16th International Conference on Human Retroviruses: HTLV and Related Viruses \\ Montreal, Canada. 26-30 June 2013
}

\begin{abstract}
Adult T cell leukemia and lymphoma (ATL) is a highly aggressive form of hematological malignancies, which is caused by chronic infection of human $\mathrm{T}$ cell leukemia virus type 1 (HTLV-1). The viral genome encodes an oncogenic protein Tax that plays a key role in trans activating viral gene transcription and in deregulating cellular oncogenic signaling to promote survival and proliferation of virally infected T cells. Hence, Tax is a desirable therapeutic target, particularly at early stage of HTLV-1-mediated oncogenesis. We here show that niclosamide, an anti-helminthic molecule, induced apoptosis of HTLV-1-transformed T cells. Niclosamide promoted formation of polyubiquitinated Tax protein aggregate, facilitating its subsequent degradation in proteasome. Consistent with niclosamide-mediated Tax degradation, the transcription of HTLV-1 viral genes is suppressed. Furthermore, niclosamide inhibited the activities of MAPK/ERK and Stat3, and down regulated prosurvival Bcl-2 family members such as Mcl-1. Since Tax, Stat 3 and Mcl-1 are growth-promoting molecules in HTLV-1-transformed T cells, our data demonstrated a novel mechanism of niclosamide in inducing polyubiquitination-dependent degradation of Tax and certain cellular pro-survival molecules, thereby promoting apoptosis of HTLV-1-associated leukemia.
\end{abstract}

\section{Authors' details}

${ }^{1}$ Institute of Human Virology, University of Maryland School of Medicine, Baltimore, MD, USA. ${ }^{2}$ Penn State Hershey Cancer Institute, Hershey, PA, USA.

Published: 7 January 2014

\footnotetext{
* Correspondence: hcheng@ihv.umaryland.edu

'Institute of Human Virology, University of Maryland School of Medicine, Baltimore, MD, USA

Full list of author information is available at the end of the article
}

doi:10.1186/1742-4690-11-S1-P148

Cite this article as: Xiang et al:: Ubiquitination-dependent, proteasomal degradation of the retroviral oncoprotein Tax by niclosamide, an anti-helminthic molecule. Retrovirology 2014 11(Suppl 1):P148.
Submit your next manuscript to BioMed Central and take full advantage of:

- Convenient online submission

- Thorough peer review

- No space constraints or color figure charges

- Immediate publication on acceptance

- Inclusion in PubMed, CAS, Scopus and Google Scholar

- Research which is freely available for redistribution

Submit your manuscript at www.biomedcentral.com/submit
() Biomed Central 